\title{
The Characteristics, positioning and Roles of Learning Party Organizations in Impoverished Villages
}

\author{
Dan $\mathrm{Lu}^{1, \mathrm{a}, *}$, Jingyan Duan ${ }^{2, \mathrm{~b}}$ and Ping $\mathrm{He}^{2, \mathrm{c}}$ \\ ${ }^{1}$ School of Finance and Public Administration, Yunnan University of Finance and Economics, Kunming \\ 650221, China \\ ${ }^{2}$ School of International Business, Yunnan University of Finance and Economics, Kunming 650221, China \\ ayufejennyludan@126.com, b20025859@qq.com, ‘404249516@qq.com \\ *corresponding author
}

Keywords: Impoverished villages, learning Party organization, characteristics, positioning, roles

\begin{abstract}
This paper defines the connotations and characteristics of the learning Party organization of impoverished villages. Based on the objective tasks, it analyzes the organizational functions and roles to build the learning Party organization of impoverished villages. According to the farmers' real demands, this paper provides suggestions on the Party organizational direction development about politics, economy and society, and it also points out the role should play around the Party construction, production and daily life. Besides, this paper will focus on characteristics, positioning and roles of learning Party organizations, and then play organizational roles to improve work efficiency effectively, helping poor farmers out of poverty, and increasing speed of economic development.
\end{abstract}

\section{Introduction}

Constitution of the Chinese Communist Party summarized the status and function of the Party organizational primary level as: "the Party organizational primary level is the fighting fort, which is the foundation of the Party's all jobs and capacities." The learning Party organization of impoverished villages play kinds of roles, such as organizational foundation, the core of leadership, the bases of all organizational jobs and capacities, which take key responsibilities of contacting the mass, publicizing, organizing the mass, uniting the mass, and practice relevant policies and guides. Because of historic, social, and natural reasons, constructing the learning Party organization strenuously is an extremely important and urgent strategic task for all Party organizational levels of impoverished villages.

\section{The traits analysis of impoverished villages' learning Party organization}

\subsection{The connotation}

Firstly, from the macro graphic perspective, the impoverished villages' learning organizational Party based on the theory of Marxism-Leninism and the theory of village primary level construction. The organization is built as arming scientific theory, opening the vision, seizing the modern rural construction rules, and innovating learning Party organizations at the primary level. Based on the learning Party organization construction, impoverished area will be developed as a modern socialist countryside with production increasing, life wealthy, social polite, environmental clean and tidy, which will consolidate the core position of the Party organizational primary level ${ }^{[1]}$. Secondly, from the perspective of function orientation, the learning Party organization is defined as the Party organization lead Party cadres and members improve their abilities and capabilities, and organize impoverished villagers studying together. Finally, from the organizational structure perspective, the learning Party organizations of impoverished villages include: village Party committee, general branch, and Party group. 


\subsection{Characteristics of learning Party organizations of impoverished villages}

Politics is the essential characteristic of the learning Party organization of impoverished villages. The principles of the learning Party organization include political awareness and emphasizing the Party spirit, which make the ideological and political literacy of Party organizations and Party members at the top priority.

The most important barriers of the construction and development of learning Party organizations in impoverished villages are the static nature of the regional economy, which shows as slow development, and resulting in a weak economic situation.

The inner characteristics of impoverished villages' learning Party organizations are loose and weak cohesive. The good mass foundation is the political core of learning Party organizational primary level, which is the key of forming cohesive. Because of the conflict between some impoverished villages' learning Party organizations and farmers, the mass cohesive is hard to be formed.

A basic characteristic of impoverished villages' learning Party organizations in is lacking strategic consideration. There are some problems, such as low enthusiasm, lacking learning activities, and limited organizational abilities. The further reasons are lacking of strategic considerations about learning Party organizational construction, and only focus on details of technology or management. Therefore, these reasons lead primary Party cadres cannot contact Party building with daily jobs, and unable to build learning Party organizations during a long time ${ }^{[2]}$.

The essential characteristic of the impoverished villages' learning Party organization is durative. According to requirements of Party building work, durative is a kind of comprehensive studies, which not only include political knowledge study, but also include studies of agricultural expertise and rural working skills.

\section{The position and function of the learning Party organization in against poverty}

\subsection{The objective tasks of the learning Party organizations of impoverished villages}

Promoting rural economy development. There are many problems of economic development in contemporary rural areas. For example, how to rural areas guide and solve the rural surplus labor transfer and export. How to rural areas effectively improve skills of farmers. How to rural area guide farmers focus on both current economic interests and the long-term economic development. Developing and building the learning Party organizations will provide powerful intelligence and theoretical support to rural areas. The basic goal of building learning Party organizations of impoverish villages are to leave out of poverty, which will make rural economy developing rapidly and healthily. The main ways of left out of poverty are targeted poverty alleviation and basic-level Party organizations' building, which require the rural primaryParty organizations to serviceall poor families. The grassroots party organizations need to promote targeted poverty alleviation, and strengthen the construction of primary Party organizations ${ }^{[3]}$.

Promoting cultural and ideological progress of rural areas. Nowadays, impoverished villages are in the critical situation of great development and change. Almost famers already solved the problem of food and clothing, and their lives become richer. However, comparing with improving life standards, rural cultural life cannot meet the requirement of the higher level spiritual needs of famers. The creation and development of the learning Party organizations will provide strong organizational guarantee and powerful drive. According to the propaganda and promotion of the primary learning Party organizations, the socialist core value system will be the creeds pursuit and behavior standard of famers ${ }^{[4]}$.

Constructing the new socialist rural areas. The process of constructing the new socialist countryside includes adjusting agricultural structure, increasing the income of farmers, and developing modern agriculture. As the foundation of the Party's governance of the countryside, the rural Party organizations lead farmers getting richer and more harmonious. 


\subsection{Roles and functions of learning Party organizations of impoverished villages}

\subsubsection{Roles of the learning Party organizations of impoverished villages}

Carry out and practice the Party's guidance, principles and policies to guarantee the completion of production and work tasks for reflecting roles of the learning Party organizations. In the process of implementing the Party's line, principle and policy, rural grassroots party organizations play a particularly important role. Grassroots party organizations should correctly understand and firmly implement the Party's line, principles, policies and resolutions, and keep highly consistent with the central committee. Besides, the grassroots party organization need to combine the line, principles, policies and resolutions with the actual work, which can check the effectiveness of the grassroots party organizational construction.

Strengthening the Party's construction, and setting Party members as models. The Party need to strengthen the own construction, which includes governing over the Party strictly, educating the Party members, and setting Party members as models. The roles of the learning Party organization of the impoverished village include strengthening the Party's construction, educating and managing the Party members, and setting rural Party members as models.

Contacting with the mass tightly, consolidating the foundation of the Party governance, and safeguarding the Party's strength.The mass are the source of the Party's strength and victory. Without endorse and support of the mass, the Party can do nothing. The grassroots party organizations take many responsibilities, such as contacting the mass, publicizing the mass, organizing the mass, and uniting the mass.

\subsubsection{The functional orientation of the learning Party organization in the impoverished villages}

Leadership core and battle fortress. The learning Party organization of the impoverished village has following functions, which includes the leading core of the new rural construction, the base of the Party work and effectiveness, providing an important link with the mass, the determinant of the Party's objectives.

Developing modern agriculture and leading famers richer. With social economy developing rapidly, farmers gradually show a "interest awakening" in their daily production and lives, which rises their enthusiasm to lift themselves out of poverty. Famers increase demands of their good lives, which include improving basic production and living conditions, gaining more market information, and grasping practical scientific technologies.

Serving the famers and uniting the mass. Serving famers is the learning Party organizational inner function of the impoverished villages. As the front line of the mass, the grassroots party organizations should manage the relationship between the Party and famers better, and take the famer service as own responsibilities and obligations.

Maintaining rural stability and promoting social harmony. That are political tasks and political responsibilities of rural grassroots party organizations for a long time. Rural grassroots party organizations should play roles as coordinating interest relations, mitigating conflicts, and integrating differences to integrate different interests.

\section{Roles of grassroots Party organizations in against poverty of impoverished villages}

\subsection{The farmers' realistic demands of impoverished villages}

Increasing farmers' incomes effectively. Developing the agricultural industry and strengthen the "blood-forming" functions are the fundamental demands of the villagers. Since most impoverished villages are located in the western mountainous areas, infertile land, mountain forest, grassland, desert, and swampland are the basic living resources for the poor villagers. Developing and utilizing existing resources are the realistic choice and fundamental ways to against poverty. Promoting agricultural industry development, and increasing farmers' income effectively are the primary tasks for the impoverished grassroots Party organizations. 
Strengthening labor skills and improving migrant work standard are important channels to increase famers' income. Nowadays, migrant working is the first option of surplus labor in impoverished areas. The migrant working salary occupies the main proportion of famers' total income. Because of the low education levels, improving famers' labor skills and abilities to meet the needs of the labor market, is the important tasks for all levels to against poverty. Besides, it is a key point of rural grassroots Party organizations.

Improving medical security and education effectively. Since low medical security standards of rural areas, famers are easy to return to poverty by serious disease or long-term illness. Another reason for famers return to poverty is taking children tuition fee.

Adding cultural facilities and improve life quality. The most important issue in current rural area is many young people working out in developed and developing cities, which cause the aged people, women and children stay at home without thoughtful attention. Therefore, the grassroots Party organizations should perfect rural culture activities and facilities to make villagers healthier. At the same time, there organizations need to rich villagers' daily lives, and improve their life standards by television and radio programs.

Participating rural administrations. Comparing with developed and developing areas in China, the developing speed is slower, and the situation is changed just a little, which cause poor villagers are not satisfied with their living situations and the Party organization. Therefore, participating in village administrations can tight the relationship between Party cadres and the mass, and improve understanding and supporting of villagers to resolve the rural conflicts.

\subsection{Transforming and playing roles of grassroots Party organizations}

\subsubsection{The role of grassroots party organizations}

Chairman Xi Jinping pointed out that poverty alleviation should be practical and realistic. Poverty alleviation should avoid unrealistic slogans and objectives. Grassroots Party organizations should transform their roles actively to meet the villagers' needs.

Political role. The learning Party organizations of the impoverished villages take the functions of guidance, rather than dominance, which keep consistent with the villagers' autonomy. The premise of villagers' self-government is to recognize the leadership of the grassroots Party organization. The grassroots Party organization has established the guidance for the village affairs in the political process, which improve the understanding and implementation of the policy to complete poverty alleviation successfully.

Economic role. The grassroots Party organizations are from doing nothing to doing well in impoverished villages. There is a conflict between individual career development and low education level of famers, which needs helps of the grassroots Party organizations.

Social role. The grassroots Party organizations should change its role from manager to server. The Party organization can keep the tight relationship with villagers to hear their requirements. Therefore, the Party organization should enhance the consciousness and gain the ability to serve the mass, which will improve the satisfaction of the villagers. At the same time, the satisfactions of the mass will increase their happiness.

\subsubsection{Playing the role of grassroots Party organizations}

The Party building factor. Firstly, completing the model setting should strengthen the leader team construction, and promote standardization of the grassroots Party organization. Besides, the model setting should reinforce the masses education to promote rural policies implementation. Secondly, these organizations should strengthen the cohesion and improve identity and belonging. Thirdly, strengthen supervision and inspection of grassroots Party organizations. The grassroots Party organization should implement relevant institution, and guarantee open and fair decision procedures.

Production aspect. Currently, the primary tasks of the impoverished rural areas are to focus on "two industries", namely production and employment. The grassroots Party organizations mainly promote economic development by following aspects. Firstly, the grassroots Party organizations should encourage rural talents as leaders to lead rural development, and take the role of the backbone 
for poverty alleviation. And the getting rich first Party members need contact with impoverished Party members and villagers to help them to against poverty, which will also leading economic development of impoverished villages. Secondly, the grassroots Party organizations should do following affairs to improve abilities of getting rich. There affairs include developing collective economy with local conditions and natural resources, understanding local agricultural characteristics, playing and publicizing local special advantages, carry out e-commerce platform in an all-round way in rural areas to drive the economy development in the long-term.

Daily life aspect. The grassroots Party organizations should build harmonious and civilized modern villages by understanding the mass needs. The organizations need to start with the following points. Firstly, the organizations should fully understand the mass, and concern for their needs and requirements. And then, the organizations should accord to these needs and requirements to play the exemplary role. Secondly, the grassroots Party organizations should pay close attention to destitute population. The key of poverty alleviation is "targeted poverty alleviation", which requires the organizations full understand reasons of poverty and actual situations. The targeted poverty alleviation can help destitute population to find the most suitable methods to eliminate poverty. Thirdly, the grassroots Party organizations need to manage all kind of relationships and conflicts well, such as relationship between the Party and the mass, the relationship between cadres and the mass, and conflicts among them. The harmonious relationships are good for daily works and recognitions of the mass. Finally, the grassroots Party organization should combine the social organizations to carry spiritual civilization activities, which can enrich the mass leisure life, and enhance the mass awareness of environmental protect.

\section{Conclusion}

The report of the 18th National Congress of the Communist Party of China stated out comprehensively improve the level of the Party construction level, and it impelled the learning Party organizations development with learning oriented, service oriented, and create oriented. Creating the learning oriented, service oriented, and create oriented are a series of objective system of the learning Party organizations. In the organization construction process, the organizations should take learning orientation as foundation, service orientated as core and key, creating orientation as energy and guarantee, which supplement each other. The organizations should carry out all sorts of works effectively, and improve abilities and levels of their work for playing roles of "the foundation of the Party's all jobs and combat effectiveness” by fully understanding the learning Party organizations of the impoverished villages.

\section{References}

[1] T. Yan, Analysis about learning-type rural branches of Communist Party construction of problems and countermeasure. Chongqing: Southwest University. 2014: 24.

[2] X. Liu and Y. Deng, Strategic management of the grassroots learning Party organization construction. Journal of Changchun Normal University (Humanities and Social Sciences), 2011-30(5):5-5.

[3] Dali Heqing: targeted poverty alleviation to get rich. 2017-07-13.

[4] Z. Xin, Discuses rural grassroots learning Party organization construction and development. The Science Education Article Collects. 2012(12):199-200. 